\title{
Dynamics of experimental infection with Leptospira serogroup Pomona in different
}

\section{sheep breed}

\author{
Dinâmica da infecção experimental com Leptospira sorogrupo Pomona em diferentes raças de \\ ovinos
}

Dinámica de la infección experimental con Leptospira serogrupo Pomona en diferentes razas de ovinos

\author{
Diego Figueiredo da Costa \\ ORCID: https://orcid.org/0000-0002-2698-2060 \\ Universidade Federal da Paraíba, Brazil \\ E-mail: diegoveter@hotmail.com \\ Davidianne de Andrade Morais \\ ORCID: https://orcid.org/0000-0002-5031-1419 \\ Universidade Federal de Campina Grande, Brazil \\ E-maildavidianneandrademorais@gmail.com \\ Aline Ferreira da Silva \\ ORCID: https://orcid.org/0000-0002-1472-8372 \\ Universidade Federal de Campina Grande, Brazil \\ E-mail: aline_ferreirabsf@hotmail.com \\ Ismael Lira Borges \\ ORCID: https://orcid.org/0000-0002-1856-1717 \\ Universidade Federal de Campina Grande, Brazil \\ E-mail: ismael.borges@aluno.uece.br \\ Jefferson da Silva Ferreira \\ ORCID: https://orcid.org/0000-0002-0405-3738 \\ Universidade Federal de Campina Grande, Brazil \\ E-mail: jeffersonpatovet@gmail.com \\ Camila de Sousa Bezerra \\ ORCID: https://orcid.org/0000-0002-4775-2555 \\ Universidade Federal de Campina Grande, Brazil \\ E-mail: camila_cstr.mv@ @otmail.com \\ Carla Lauise Rodrigues Menezes Pimenta \\ ORCID: https://orcid.org/0000-0002-4327-2191 \\ Universidade Federal de Campina Grande, Brazil \\ E-mail: carlalauise@ hotmail.com \\ Maria Luana Cristiny Rodrigues Silva \\ ORCID: https://orcid.org/0000-0002-1367-3816 \\ Universidade Federal de Campina Grande, Brazil \\ E-mail: luacristiny@yahoo.com.br \\ Sergio Santos de Azevedo \\ ORCID: https://orcid.org/0000-0002-1777-7348 \\ Universidade Federal de Campina Grande, Brazil \\ E-mail: sergio@vps.fmvz.usp.br \\ Clebert José Alves \\ ORCID: https://orcid.org/0000-0002-8187-955X \\ Universidade Federal de Campina Grande, Brazil \\ E-mail: clebertja@uol.com.br
}

\begin{abstract}
Most of the information about leptospirosis was obtained from experimental infections with rodents, which in spite of being relevant, do not provide all the answers about the disease in animals and human beings, given the variability of interactions which exist between the agent and the different hosts. Therefore, the objective of the present study was to verify the pathogenesis of the infection in native breeds of sheep of Brazil challenged with a strain of the serogroup Pomona. A total of 10 sheep were divided into two groups with five animals according to the breed. In each group four sheep were challenged by intraperitoneal route with a strain of the serogroup Pomona and one was used as control. Sheep were monitored for 60 days, with collection of blood for serologic diagnosis, as well as vaginal fluid and urine for microbiological and molecular analyses. After this period the animals were submitted to euthanasia and
\end{abstract}


necropsy, with collection of tissues for microbiological, molecular and histopathologic diagnosis. All the challenged sheep presented anti-Leptospira antibodies. Crossbred sheep presented a lower concentration of titers and the antibodies were detected for a shorter period of time when compared to the Santa Inês sheep, with statistical difference in the concentration of the titers on the days $15(\mathrm{p}<0.05), 45(\mathrm{p}<0.05)$ and $60(\mathrm{p}<0.05)$ post-infection. There was no significant difference between the groups when comparing the positivity rates of the microscopic agglutination test (MAT) $(\mathrm{p}>0.05)$. Eight positive reactions in the urine and vaginal fluid PCR were detected in both groups, being four $(50 \%)$ in urine and four $(50 \%)$ in the vaginal fluid, however without statistical difference $(\mathrm{p}>0.05)$. In both groups there was a greater proportion of PCR positive samples in kidneys $(71.4 \%)$ in relation to uterus $(28.6 \%)$, however without significant difference $(p>0.05)$. There was no significant difference between the groups when comparing the positivity rates of the PCR $(p>0.05)$. The isolation of leptospires from the urine and kidney of a crossbred sheep was possible. Therefore, it is possible that the native sheep, especially the crossbred, may have a relation of resistance with strains of the serogroup Pomona. However the intensity and duration of this relation need to be elucidated and longer-lasting investigations of natural and experimental infections are necessary in order to determine the epidemiological nature of this relation.

Keywords: Resistance; Leptospirosis; Santa Inês; Crossbred sheep; Pomona.

\section{Resumo}

A maioria das informações sobre a leptospirose foi obtida a partir de infecções experimentais com roedores, que apesar de relevantes, não fornecem todas as respostas sobre a doença em animais e seres humanos, dada a variabilidade de interações existentes entre o agente e os diferentes hospedeiros. Portanto, o objetivo do presente estudo foi verificar a patogênese da infecção em raças nativas de ovinos do Brasil desafiados com uma cepa do sorogrupo Pomona. Um total de 10 ovelhas foram divididas em dois grupos com cinco animais de acordo com a raça. Em cada grupo quatro ovelhas foram desafiadas por via intraperitoneal com uma cepa do sorogrupo Pomona e uma foi utilizada como controle. As ovelhas foram acompanhadas por 60 dias, com coleta de sangue para diagnóstico sorológico, bem como de secreção vaginal e urina para análises microbiológicas e moleculares. Após esse período os animais foram submetidos à eutanásia e necropsia, com coleta de tecidos para diagnóstico microbiológico, molecular e histopatológico. Todas as ovelhas desafiadas apresentaram anticorpos anti-Leptospira. Ovinos mestiços apresentaram menor concentração de títulos e os anticorpos foram detectados por menor período de tempo quando comparados aos ovinos Santa Inês, com diferença estatística na concentração dos títulos nos dias 15 (p <0,05), 45 (p < 0,05) e 60 ( p <0,05) pós-infecção. Não houve diferença significativa entre os grupos ao comparar as taxas de positividade do teste de aglutinação microscópica (MAT) ( $>$ > 0,05). Oito reações positivas na PCR de urina e fluido vaginal foram detectadas em ambos os grupos, sendo quatro (50\%) na urina e quatro $(50 \%)$ no fluido vaginal, porém sem diferença estatística ( $p>0,05)$. Em ambos os grupos houve maior proporção de amostras positivas para PCR em rins $(71,4 \%)$ em relação ao útero $(28,6 \%)$, porém sem diferença significativa ( $\mathrm{p}>0,05)$. Não houve diferença significativa entre os grupos ao comparar as taxas de positividade da PCR ( $>>0,05)$. O isolamento de leptospiras da urina e rim de ovelhas mestiças foi possível. Portanto, é possível que ovinos nativos, principalmente os mestiços, tenham relação de resistência com linhagens do sorogrupo Pomona. No entanto, a intensidade e a duração dessa relação precisam ser elucidadas e investigações mais duradouras das infecções naturais e experimentais são necessárias para determinar a natureza epidemiológica dessa relação.

Palavras-chave: Resistência; Leptospirose; Santa Inês; Ovelha cruzada; Pomona.

\section{Resumen}

La mayor parte de la información sobre la leptospirosis se obtuvo de infecciones experimentales con roedores, que a pesar de ser relevantes, no brindan todas las respuestas sobre la enfermedad en animales y seres humanos, dada la variabilidad de interacciones que existen entre el agente y los diferentes hospedadores. Por lo tanto, el objetivo del presente estudio fue verificar la patogénesis de la infección en razas nativas de ovejas de Brasil desafiadas con una cepa del serogrupo Pomona. Un total de 10 ovejas se dividieron en dos grupos con cinco animales según la raza. En cada grupo, cuatro ovejas fueron desafiadas por vía intraperitoneal con una cepa del serogrupo Pomona y una se usó como control. Las ovejas fueron monitoreadas durante 60 días, con recolección de sangre para diagnóstico serológico, así como fluidos vaginales y orina para análisis microbiológicos y moleculares. Luego de este período los animales fueron sometidos a eutanasia y necropsia, con recolección de tejidos para diagnóstico microbiológico, molecular e histopatológico. Todas las ovejas desafiadas presentaron anticuerpos anti-Leptospira. Los ovinos mestizos presentaron menor concentración de títulos y los anticuerpos se detectaron por un período de tiempo más corto en comparación con el ovino Santa Inês, con diferencia estadística en la concentración de los títulos en los días 15 (p <0.05), 45 (p< $0,05)$ y $60(\mathrm{p}<0,05)$ post-infección. No hubo diferencia significativa entre los grupos al comparar las tasas de positividad de la prueba de aglutinación microscópica (MAT) ( $>$ > 0.05). Se detectaron ocho reacciones positivas en la PCR de orina y fluido vaginal en ambos grupos, siendo cuatro $(50 \%)$ en orina y cuatro $(50 \%)$ en fluido vaginal, sin embargo sin diferencia estadística $(\mathrm{p}>0.05)$. En ambos grupos hubo una mayor proporción de muestras positivas a PCR en riñones $(71,4 \%)$ en relación al útero $(28,6 \%)$, sin embargo sin diferencia significativa ( $\mathrm{p}>0,05)$. No hubo diferencia significativa entre los grupos al comparar las tasas de positividad de la PCR (p>0.05). Fue posible el aislamiento de leptospiras de la orina y el riñón de una oveja mestiza. Por tanto, es posible que la oveja autóctona 
brasileña, especialmente la mestiza, pueda tener una relación de resistencia con cepas del serogrupo Pomona. Sin embargo, es necesario dilucidar la intensidad y duración de esta relación y se necesitan investigaciones más duraderas de las infecciones naturales y experimentales para determinar la naturaleza epidemiológica de esta relación.

Palabras clave: Resistencia; Leptospirosis; Santa Inês; Oveja mestiza; Pomona.

\section{Introduction}

Leptospirosis is an infectious and contagious disease caused by bacteria of the genus Leptospira which has a negative impact on the productive and reproductive rates of the herds, besides being an important zoonosis (Ellis, 2015). A recent systematic review found about one million cases of human leptospirosis per year worldwide, resulting in a mortality rate of approximately 6\% (Costa et al., 2015). The transmission of leptospirosis is mainly influenced by environmental conditions, especially rainfall indices (Correia et al., 2017). However, in situations in which the environmental conditions are adverse the animal reservoirs have an expressive importance in the epidemiology of the disease (Picardeau, 2013). In this context, it is assumed that in the semiarid region the interaction between sheep and the etiologic agent happens differently from the other places, due to the uniqueness of the weather conditions and vegetation (Costa et al., 2016).

Some Leptospira serovars are commonly adapted to specific hosts (Pinto et al., 2016), however an in-depth analysis of this adaptation and the relation of adaptability of strains with certain animal hosts may be being neglected. For a long time it was believed that sheep participated only as accidental hosts of leptospirosis and that the infection depended directly of the action of other species, mainly cattle (Vermunt et al., 1994). Notwithstanding, experimental studies and field observations indicate an independence of the participation of other species in the infection (Martins, \& Lilenbaum, 2014), moreover sheep are already cited as an alternative source of maintenance of the serovar Hardjo (Lilenbaum et al., 2009; Arent et al., 2017a).

There are few reports on clinical manifestations in sheep (Martins, \& Lilenbaum, 2014), therefore, it is believed that this species may also has a possible resistance to other strains, not only to the Hardjo. The serogroup Pomona is one of the most recovered in the world and various strains have the swine as a maintenance host (Ellis, 2012). Although this serogroup causes an acute clinical infection and is economically significant in various animal species (Arent et al., 2017b), recent reports indicate an increase in the incidence and endemism of this serogroup in sheep in some areas (Vallée et al., 2017). Furthermore, these animals have been incriminated as being risk factors for other species in infections involving this serogroup (Subharat et al., 2012)

Most of the information about leptopirosis was obtained from experimental infections with rodents, which in spite of being relevant do not supply all the answers about the pathogenesis of the disease in animals and human beings, due to the variability of interactions which exist between the agent and the different hosts (Gomes-Solecki, Santecchia, \& Werts, 2017). Therefore, knowing that the breeds of sheep have showed to be expressive asymptomatic carriers of the agent (Silva et al., 2018), as well as the environmental cycle of the leptospires is influenced by regional factors and by the dynamic nature of the strains/animal species involved (Barragan et al., 2017), the objective of the present study was to verify the pathogenesis of the infection in sheep challenged with the strain L. interrogans serogroup Pomona.

\section{Methodology}

The present research obtained approval from the Committee of Research Ethics (CEP) at the Federal University of Campina Grande (UFCG), Protocol n. 020/2016. The trials in hamsters were performed after the approval of Animal Ethics Committee of the Universidade Federal Fluminense (protocol number 611/2015). 


\subsection{Selection of the animals}

The experiment was conducted at the Research Center for the Development of the Semiarid Tropic (Nupeárido) of the UFCG, State of Paraíba, Brazil. For the experimental infection, 10 sheep were used aged between 12 and 18 months, average body weight of $26 \mathrm{Kg}$, not vaccinated for leptopirosis and which presented negative at serology (MAT titer $\leq 50$ ), bacterial culture and PCR (urine and vaginal fluid) in three previous analysis with intervals of 30 days. The sheep were divided into groups according to the breed, being five crossbred (Group A) and five of the Santa Inês breed (Group B). All animals were accommodated in individual covered stalls $(1.0 x 1.5 \mathrm{~m})$ without contact with other animals, distant from the soil at a height of $1 \mathrm{~m}$ and with access to water and food ad libitum. The animals underwent an adaptation in the installations 20 days before the challenge.

\subsection{Virulence test and experimental infection}

In each of the experimental groups (A and B) four animals were challenged with $10^{7}$ bacteria of the L. interrogans serogroup Pomona serovar Kennewicki (strain Fromm) isolated from pigs in Brazil (Miraglia et al., 2015). The virulence tests followed suggested protocols (Silva et al., 2008; Suepaul et al., 2010) with slight modifications (Barbosa; Martins, \& Lilenbaum, 2016). The 3Rs policy for experimental science was applied in all steps (Barbosa; Martins, \& Lilenbaum, 2016) in accordance with the Brazilian Guidelines of the Federal Council of Veterinary Medicine and Brazilian Guideline for the Care and Use of Animals for Scientific and Didactic Purposes. The strain underwent four passages in Golden Syrian hamsters as described by Silva et al. (Silva et al., 2008) and Suepaul et al. (2010) with adaptations (Barbosa; Martins, \& Lilenbaum, 2016). Used the strain starting after the fourth passage in hamster.

The strain was maintained in EMJH medium (DIFCO, BD, Franklin Lakes, NJ, EUA), whilst one animal in each group received only liquid EMJH culture media without the bacterial culture. The bacterial count was carried out with the aid of a Neubauer chamber in a dark-field optical microscope, in which was reached a volume of $2 \mathrm{~mL}$ that were inoculated through intraperitoneal route (IP). Within the 60 days following the inoculation, collections of blood, urine and vaginal fluid were performed from all the sheep on days $04,08,15,30,45$ and 60 post-infection (p.i.), thus totaling six collections. Throughout the trials, clinical signs (pyrexia, prostration, jaundice, hematuria, dyspnea, polypnea, tachycardia, bradycardia, dehydration and color of mucosae) were monitored. The total time of experiment and the quantity of collections was regulated by the ethics committee in animal experimentation. After the last collection the sheep were submitted to euthanasia, being previously sedated with Xylazine Hydrochloride (Bayer, Rompun ${ }^{\circledR}$, São Paulo, SP, Brazil) at a dose of $0.2 \mathrm{mg} / \mathrm{kg}$ by endovenous route, followed by the administration of Sodium Thiopental (Cristália, Thiopentax ${ }^{\circledR}$, São Paulo, SP, Brazil) at a dose of $10 \mathrm{mg} / \mathrm{kg}$ intravenously and, after the confirmation of unconsciousness, Potassium Chloride was administered (Synth, Potassium Chloride P.A.-A.C.S ${ }^{\circledR}$, Diadema, SP, Brazil) at a dose of $100 \mathrm{mg} / \mathrm{kg}$ intravenously. Finally, the necropsy was carried out for the verification of the possible anatomopathological alterations and collection of material for the microbiological, histological and molecular diagnosis.

\subsection{Collection of samples}

The blood was collected by puncture of the jugular vein, using a disposable needle and a $8 \mathrm{~mL}$ vacuum tube (without anticoagulant) (Vacuum Tube, Vacuette ${ }^{\circledR}$, Porto, Portugal), subsequently to the local antisepsis with $2 \%$ iodinated alcohol solution. The serum was drained from the blood, transferred to microtubes, and frozen at $-20{ }^{\circ} \mathrm{C}$ until further processing. With a vaginal speculum, urine samples were collected by means of a no. 8 sterile urethral probe, and were extracted using disposable sterile syringes. For the molecular analysis, aliquots of urine $(2 \mathrm{~mL})$ were distributed in microtubes containing 100 $\mu \mathrm{L}$ of PBS 10X. Samples of vaginal fluid were obtained in duplicate, collected directly from the vaginal fornix with the use of 
disposable sterile swabs (Labor Import, Ref: 25507, Osasco, SP, Brazil) and the aid of a vaginal speculum. The second sample of vaginal fluid collected was immersed into a sterile tube with $2 \mathrm{~mL}$ de PBS 10X, homogenized and aliquoted in microtubes. The aliquots were immediately refrigerated and transported within two hours to the laboratory, and were stored at $-20^{\circ} \mathrm{C}$ until the DNA extraction was carried out.

During the necropsy, fragments $\left(2 \mathrm{~cm}^{2}\right)$ of kidney, ovary, uterine tube, uterus, bladder, lung, liver and spleen were aseptically collected in triplicate. One sample was processed and sown in proper culture media for the microbiological diagnosis, the second was stored and fixed in $10 \%$ formaldehyde buffer, being posteriorly submitted to staining with hematoxylin-eosin (HE) and microscopic evaluation, while the third sample was stored at $-20^{\circ} \mathrm{C}$ until the DNA extraction was carried out. In the tissue samples, the DNA extraction was performed only of the kidney and uterus.

\subsection{Bacteriological culture}

At the time of the collections, some drops of urine and a vaginal fluid swab were sewn in EMJH culture medium in the concentration of $10 \%$, supplemented with a antimicrobial cocktail (Chakraborty et al., 2011). The seeded tubes were kept at room temperature until transport to the laboratory and then incubated at $28^{\circ} \mathrm{C}$ in a bacteriological oven. After 24 hours in STAFF medium, the tubes were submitted to serial dilution $\left(10^{-1}, 10^{-2}, 10^{-3}\right)$ in Fletcher semi-solid medium (Difco, BD, Franklin Lakes, NJ, EUA), with the addition of 5-Fluorouracil $(1 \mathrm{mg} / \mathrm{mL}-1)$ and incubated at $28^{\circ} \mathrm{C}$, and were examined weekly regarding the presence of Leptospira sp. during the period of 12 weeks. The tissue samples obtained during the necropsy were macerated with the aid of sterile disposable needles and sown in proper culture medium, as previously described. A culture was deemed positive when the sample was suspected at microscopy and confirmed by PCR.

\subsection{Serological diagnosis}

A serological diagnosis of leptospirosis was made using the microscopic agglutination test (MAT), as recommended by the World Organization for Animal Health (OIE, 2014). Serum samples were researched regarding the presence of antibodies using the dilution of 1:100 against one bacterium of 24 serovars. In the analysis, the strains used were: Leptospira biflexa: serovars Andamana and Patoc; Leptospira interrogans: Autumnalis, Kennewicki, Australis, Copenhageni, Bataviae, Bratislava, Canicola, Grippotyphosa, Hardjoprajitno, Pomona, Pyrogenes, Icterohaemorrhagiae, Hebdomadis, Wolffi,; Leptospira borgpeterseni: Castellonis, Hardjobovis Javanica, Tarassovi, Leptospira santarosai: Guaricura, Shermani; Leptospira kirschneri: Cynopteri; Leptospira noguchii: Panama. The sera which presented 50\% or more of agglutination in the indicated dilution were titled in a series of geometric dilutions in ratio 2 . The title of the serum was reciprocal of the highest dilution which presented a positive result.

\subsection{Molecular diagnosis}

Leptospiral DNA from the urine and vaginal fluid samples was extracted by the Wizard SV Genomic DNA Purification System (Promega, Madison, USA). For kidney and uterus samples, DNA was extracted by the Qiagen DNeasy Blood \& Tissue kit. A PCR targeting the lipL32 gene (referred as specific for pathogenic leptospires) was performed as described (Hamond et al., 2014). Primers LipL32-45F (5'-AAG CAT TAC CGC TTG TGG TG-3 ') and Lip L32-286R (5'GAA CTC CCA TTT CAG CGA TT-3') were used to amplify the gene LipL32, which is specific for pathogenic leptospiras (Stoddard et al., 2009). The strain L. interrogans serogrupo Pomona sorovar Kennewicki was used as a positive control and ultrapure water as negative control. Additionally, in order to minimize the effect of PCR inhibitors, the samples were neutralized to $\mathrm{pH} 7.6$ with phosphate-buffered saline (PBS), immediately after collection (Lucchesi et al., 2004). 


\subsection{Histopathological diagnosis}

A part of the fragments of the tissues collected were stored and fixed in $10 \%$ buffered formalin, cleaved and routinely processed in the histopathological, going through the stages of dehydration in increasing concentrations of alcohol,

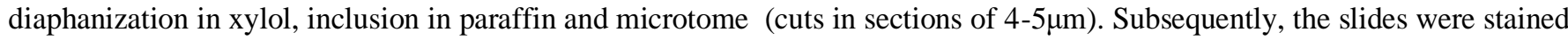
with hematoxylin-eosin (HE) and analyzed under optical microscopy.

\subsection{Statistical analysis}

The Mann-Whitney U test was used to compare the median of the antibody titers between the groups in each day post-infection. The comparison of the positivity rates of in the serology, PCR and cultivation among the groups was performed by Fischer's exact test. The level of significance used was 5\%.

\section{Results}

According to Table 1, all the challenged sheep presented anti-Leptospira antibodies at MAT, however there was no significant difference when comparing the positivity rates between the groups $(\mathrm{p}>0.05)$. Detectable antibodies were observed for a shorter period of time in the group of crossbred animals (Group A). The sheep of the crossbred group presented on D15 (median 400, geometric mean 400), D45 (median 300, geometric mean 282) and D60 (median 50, geometric mean 141) antibody titer significantly different $(\mathrm{p}<0.05)$ from Santa Inês sheep group, which presented median 800 and geometric mean 951 on D15, median 800 and geometric mean 672 on D45, and median 600 and geometric mean 565 on D60. In PCR, there was no significant difference with relation to the positivity rate between the groups ( $p>0.05)$. It were detected in both groups eight positive reactions in the PCR of urine and vaginal fluid, being four of them (50\%) in urine and four (50\%) in the vaginal fluid, however without statistical difference when positive reactions in urine and vaginal fluid were compared ( $>0.05)$. In both groups it was found a greater proportion of positive samples of kidney (71.4\%) in relation to those of the uterus (28.6\%), however there was no significant difference ( $p>0.05$ ). Leptospiral DNA was found for a longer period of time in the vaginal fluid (D60) than in the urine (D45). The isolation of leptospires was possible from the urine (D30) and the kidney (D60) in one crossbred sheep (A4). Negative control animals were negative for serology, isolation and PCR. Apparent clinical signs were not identified in any of the animals during the experiment, neither anatopathological lesions suggestive of Leptospira sp. infection. 
Table 1. Distribution of the serological (MAT), molecular (PCR) and microbiological results in different breeds of sheep experimentally infected with Leptospira interrogans serogroup Pomona.

\begin{tabular}{|c|c|c|c|c|c|c|c|}
\hline Test & $\begin{array}{l}\text { Group/ } \\
\text { animal }\end{array}$ & D4 & D8 & D15 & D30 & D45 & D60 \\
\hline \multirow[t]{8}{*}{ MAT } & $\mathrm{A} 1$ & - & 400 & 400 & 200 & 200 & 100 \\
\hline & A2 & - & 800 & 400 & 400 & 200 & - \\
\hline & A3 & - & 800 & 400 & 400 & 400 & - \\
\hline & A4 & - & 800 & 400 & 400 & 400 & 200 \\
\hline & B1 & - & 1600 & 1600 & 800 & 800 & 400 \\
\hline & B2 & - & 800 & 800 & 400 & 400 & 400 \\
\hline & B3 & - & 800 & 800 & 800 & 800 & 800 \\
\hline & B4 & - & 200 & 800 & 800 & 800 & 800 \\
\hline \multirow[t]{8}{*}{ PCR/VF } & A1 & - & - & - & - & - & + \\
\hline & A2 & - & - & - & - & - & - \\
\hline & A3 & - & - & - & - & - & - \\
\hline & A4 & - & - & - & - & - & - \\
\hline & B1 & - & - & - & - & + & + \\
\hline & B2 & - & + & - & - & - & - \\
\hline & B3 & - & - & - & - & - & - \\
\hline & B4 & - & - & - & - & - & - \\
\hline \multirow[t]{8}{*}{ PCR/Urine } & $\mathrm{A} 1$ & - & - & - & + & - & - \\
\hline & A2 & - & - & - & - & - & - \\
\hline & A3 & - & - & - & - & - & - \\
\hline & A4 & - & - & - & $+*$ & - & - \\
\hline & B1 & - & - & - & + & - & - \\
\hline & B2 & - & - & - & - & - & - \\
\hline & B3 & - & - & - & - & - & - \\
\hline & B4 & - & - & - & + & - & - \\
\hline \multirow[t]{8}{*}{ PCR/ Uterus } & $\mathrm{A} 1$ & NT & NT & NT & NT & NT & - \\
\hline & $\mathrm{A} 2$ & NT & NT & NT & NT & NT & + \\
\hline & A3 & NT & NT & NT & NT & NT & - \\
\hline & A4 & NT & NT & NT & NT & NT & - \\
\hline & B1 & NT & NT & NT & NT & NT & + \\
\hline & B2 & NT & NT & NT & NT & NT & - \\
\hline & B3 & NT & NT & NT & NT & NT & - \\
\hline & B4 & NT & NT & NT & NT & NT & - \\
\hline PCR/Kidney & A1 & NT & NT & NT & NT & NT & + \\
\hline
\end{tabular}




\begin{tabular}{|c|c|c|c|c|c|c|}
\hline & NT & NT & NT & NT & NT & + \\
\hline A3 & NT & NT & NT & NT & NT & - \\
\hline & NT & NT & NT & NT & NT & $+^{*}$ \\
\hline B1 & NT & NT & NT & NT & NT & + \\
\hline B2 & NT & NT & NT & NT & NT & - \\
\hline B3 & NT & NT & NT & NT & NT & + \\
\hline & NT & NT & NT & NT & NT & - \\
\hline
\end{tabular}

Positive (+); Positive culture (*); Vaginal fluid (VF); Non tested (NT). Source: Authors.

\section{Discussion}

The results show that there was an immunological response and invasion of the tissues by the agent in the challenged animals; however a discrepancy was identified on the level of infection between the groups. Even though statistical difference was not observed in the positivity rate of the MAT between the groups ( $>0.05)$, a distinct standard in the duration and in the concentration of the antibodies was recognized. All the sheep of the Santa Inês breed were reactive in the MAT until the last collection carried out (D60), while only two of the four crossbred sheep presented positivity up to the D45 p.i., a similar result to other experimental study with sheep which used the same strain by a natural route of infection (Costa et al., 2018). Also in sheep, experimental challenges carried out with strains of the serogroup Sejroe revealed variations of detectable titers at 22 days (Rocha et al., 2018) up to 14 weeks p.i. (Sulivan, 1970), whilst that in situations of natural exposure registers of 14 and 20 months were noted for the serogroups Sejroe and Pomona, respectively (Vallée, 2015). The lack of correspondence between the studies with relation to persistence of titers may be due to the virulence of the inoculated strain, infecting dose and cut-off point used; in situations of natural infection (non-controlled) the risk of re-exposure to the agent exists and thus a greater time of detection of antibodies. However, the short period of seroreactivity in crossbred animals is surprising, thereby indicating that the infection in the species may be influenced according to the breed concerned.

Concerning the antibody concentration, the animals of the Santa Inês breed registered the highest titers, with statistical difference on D15, D45 and D60. Other reports have already described high seroconversion of antibodies in pure-bred sheep caused by strains of the serogroup Pomona, either experimentally (Costa et al., 2018) or naturally infected (Vermunt et al., 1994). However, the lower concentration of titers in crossbred sheep indicates a possible resistance of these animals against non-Sejroe strains. Apparently serovars of the same serogroup (Pomona, Monjakov and Kennewicki) have distinct interaction patterns which depend on the animal host and the environment (Ellis, 2012; Arent et al., 2017a). Therefore, it may be attributed to the fact that in some regions low frequency of antibodies for the serogroup Pomona are still reported in sheep (Martins, \& Lilenbaum, 2014), whereas in other regions this serogroup is considered to be endemic in the same species (Vallée et al., 2017). In Brazil there is no precise evidence of sheep bearing and transmitting strains of the serogroup Pomona, but due to the rusticity of the species raised in the semiarid region it cannot be ruled out that these animals may be capable, since this capacity was demonstrated in this.

Some authors have already registered problems in sheep implied to strains of the serogroup Pomona, such as miscarriages, stillborn and birth of weak lambs (Ellis et al., 1983), as well as the manifestation of acute disease in lambs presenting pale colored mucous membranes, jaundice, hemoglobinuria, hemoglobinemia and centrilobular necrosis (Vermunt et al., 1994). The sheep of this experiment did not present any clinical manifestation, not even anatomopathological lesions, similar to the reported in recent studies of experimental infections in Brazilian breeds of sheep (Costa et al., 2018; Rocha et al., 2018), however the short period of the experiment may have been a limiting factor for the presentation of lesions implied to the 
chronic phase of the disease. It is known that, despite being infectious, the serovars have a greater pathogenicity for those hosts which are not resistance (Mansell, \& Benschop, 2014), therefore the absence of clinical signs and suggestive may indicate a possible adaptability. It is worth highlighting that even without clinical signs the animals have shown to be healthy carriers of the agent, since the elimination of viable leptospires in the urine of a crossbred sheep was detected (A4). It must be admitted that experimental situations may not accurately portray reality; however, there are reports of isolation of strains of $\mathrm{L}$. interrogans serogroup Pomona serovar Kennewicki from naturally infected and asymptomatic sheep (Hamond et al., 2019). From the epidemiological point of view this may be a serious problem, as sheep may serve as a silent source of infection for other animals and human beings, and this may contribute to the negligence of the disease in the herds. Seropositive sheep for the Pomona strain have already been pointed out as a risk factor for deer which shared the same pasture to also react positively to this serogroup (Subharat et al., 2012).

The number of positive samples of vaginal fluid in the PCR was similar to the quantity of positive samples of urine in both groups; however it is probable that the intermittent elimination of the agent through the urine influenced negatively the evaluation of the elimination by this route (Costa et al., 2018; Rocha et al., 2017; Rocha et al., 2018). With this in mind, this hypothesis is further reinforced by the fact that the majority of the sheep having been renal bearers of the agent. However, the detection of the agent in the vaginal fluid and in the uterus reinforces the importance of the extra-renal site of infection and the possibility of transmission in sheep, suggested previously (Lilenbaum et al., 2008; Arent et al., 2013; Costa et al., 2018; Rocha et al., 2018; Silva et al., 2018). With relation to the capability of detecting carrier animals, the results demonstrate that only one negative result in the PCR of urine and/or vaginal fluid is inadequate to trustingly consider an animal as negative, seen as the moment of colonization of the genital tract and the period of elimination by the urine are variable. Related to the agent-host interaction, it is believed that the maintenance hosts remain infected and so a balance is established, thus creating a constant reinfection cycle controlled by a peripheral immune response that can last from months to years (Monahan; Callanan, \& Nally, 2009). The short period of the experiment did not allow the recording of these dynamics, however it is possible that if exposed the sheep may have a relation of resistance and can eliminate viable strains serogroup Pomona, even if this interaction is executed with less intensity and importance than what happens with porcine species.

\section{Conclusion}

It is possible that sheep, especially the crossbred ones, may have a relation of resistance with strains of the serogroup Pomona. However, the intensity and duration of this relation need to be elucidated. Longer-lasting investigations of natural and experimental infections are necessary to determine the epidemiological nature of this relation. Therefore, the monitoring of endemic herds and outbreaks of the disease is essential to better understand its dynamic, as well as an experimental challenge with a strain possibly adapted to sheep, as Autumnalis and Sejroe.

\section{Funding}

This work was supported by the Conselho Nacional de Desenvolvimento Científico e Tecnológico (CNPq), process number 302222/2016-2.

\section{Conflict of interest statement}

The authors have no conflicts of interest to disclose. 


\section{Acknowledgments}

Laboratory of Veterinary Bacteriology, Department of Microbiology and Parasitology (UFF); Laboratory of animal pathology-UFCG; Laboratory of Molecular Biology-UFCG; We thank J.M. Pereira Filho, Doctor, (UFCG) for assistance during the experiment.

\section{References}

Arent, Z. J., Gilmore, C., San-Miguel, A. J. M., Quevedo, N. L., \& García Peña, F. J. (2017b). Molecular Epidemiology of Leptospira Serogroup Pomona Infections among Wild and Domestic Animals in Spain. EcoHealth. 14(1), 48-57. 10.1007/s10393-017-1210-8.

Arent, Z., Frizzell, C., Gilmore, C., Mackie, D., \& Ellis, W. A. (2013). Isolation of leptospires from genital tract of sheep. Veterinary Record, 173(23), 582583. $10.1136 /$ vr.101969.

Arent, Z., Gilmore, C., Barlow, A. M., Smith, L., \& Ellis. W. A. (2017a). Leptospira interrogans serogroup Pomona infections in the UK: is there a real threat for farm animals? Veterinary Record, 180(17), 514-514. 10.1136/vr.103891corr1.

Barbosa, C. S., Martins, G., \& Lilenbaum, W. 2016. Blood collection by gingival puncture on hamsters reduces animal number in leptospirosis virulence tests. ALTEX, 33(3), 322-323.

Barragan, V., Nieto, N., Keim, P., \& Pearson, T. (2017). Meta-analysis to estimate the load of Leptospira excreted in urine: beyond rats as important sources of transmission in low -income rural communities. BMC Research Notes, 10(71), 1-7. 10.1186/s13104-017-2384-4.

Chakraborty, A., Miyahara, S., Villanueva, S. Y., Saito, M., Gloriani, N.G., \& Yoshida, S.A. (2011). A novel combination of selective agents for isolation of Leptospira species. Microbiology and Immunoogy, 55(7), 494-501. 10.1111/j.1348-0421.2011.00347.x.

Correia, L., Loureiro, A. P., \& Lilenbaum, W. (2017). Effects of rainfall on incidental and host-maintained leptospiral infections in cattle in a tropical region. Veterinary Journal, 220(1), 63-63 10.1016/j.tvj1.2016.12.016.

Costa, D. F., Silva, M. L. C. R., Martins, G., Dantas, A. F. M., Melo, M. A., Azevedo, S. S., Lilenbaum, W., \& Alves, C. J. (2018). Susceptibility among breeds of sheep experimentally infected with Leptospira interrogans Pomona serogroup. Microbial Pathogenesis, 122(1), 79-83. 10.1016/j.micpath.2018.06.017.

Costa, D. F., Silva, A. F., Farias, A. E. M., Brasil, A. W. L., Santos, F. A., Guilherme, R. F., Azevedo, S. S., \& Alves, C. J. (2016). Serological study of the Leptospira spp. infection in sheep and goats slaughtered in the State of Paraíba, semiarid of Northeastern Brazil. Semina: Ciências Agrárias, 37(2), 819-828. http://www.uel.br/revistas/uel/index.php/semagrarias/article/viewFile/20974/18600.

Costa, F., Hagan, J. E., Calcagno, J., Kane, M., Torgerson, P., Martinez-Silveira, M. S., Stein, C., Abela-Ridder, B., \& KO, A. L. (2015). Global morbidity and mortality of leptospirosis: a systematic review. PLoS Neglected Tropical Diseases. 9(9), e0003898. 10.1371/journal.pntd.0003898.

Ellis, W. A, Bryson, D. G., Neill, S. D., McParland, P. J., \&Malone, F. E. (1983). Possible involvement of leptospires in abortion, stillbirths and neonatal deaths in sheep. Veterinary Record, 112(13), 291-293. http://dx.doi.org/10.1136/vr.112.13.291.

Ellis, W. A. (2012). Leptospirosis. In Diseases of Swine. (10th ed.), Zimmerman, J. J., Ramirez, A., Schwartz, K. J. Stevenson, G. W. Wiley-Blackwell. pp 770-778. http://www.vet.unicen.edu.ar/ActividadesCurriculares/EnfermedadesInfecciosas/images/Documentos/2015/Diseases\%20of\%20Swine.\%20 J.J.Zi mmerman.\%2010th\%20Edition.\%202012.pdf.

Ellis, W.A. (2015). Animal Leptospirosis. Current Topics in Microbiology and Imunology, 387(1), 99-137. 10.1007/978-3-662-45059-8_6.

Gomes-Solecki, M., Santecchia, I., \& Werts, C. (2017). Animal models of leptospirosis: of mice and hamsters. Frontiers in Immunology, 8(58), 1-20. 10.3389/fimmu.2017.00058.

Hamond, C., Martins, G., Loureiro, A.P., Pestana, C., Lawson-Ferreira, R., Medeiros, M.A., \& Lilenbaum, W. (2014). Urinary PCR as an increasingly useful tool for an accurate diagnosis of leptospirosis in livestock. Veterinary Research Communications, 38(1), 81-85. 10.1007/s11259-013-9582-x.

Hamond, C., Silveira, C. S., Buroni, F., Suanes, A., Nieves, C., Salaberry, X., Aráoz, V., Costa, R. A., Rivero, R., Giannitti, F., \& Zarantonelli, L. (2019). Leptospira interrogans serogroup Pomona serovar Kennewicki infection in two sheep flocks with acute leptospirosis in Uruguay. Transboundary and Emerging Diseases, 66(3), 1186-1194. 10.1111/tbed.13133.

Lilenbaum, W., Varges, R., Risto, W. P., Corte, Z. A., Souza, S. O., Richtzenhain, J., \& Vasconcellos, S. A. (2009). Identification of Leptospira spp. carriers among seroreactive goats and sheep by polymerase chain reaction. Research in Veterinary Science, 87(1), 16-19. 10.1016/j.rvsc.2008.12.014.

Lilenbaum, W., Varges, R., Brandão, F. Z., Cortez, A., de Souza, S. O., Brandão, P. E., Richtzenhain, L. J., \& Vasconcellos, S. A. (2008). Detection of Leptospira spp. in semen and vaginal fluids of goats and sheep by polymerase chain reaction. Theriogenology. 69(7), 837-842. 10.1016/j.theriogenology.2007.10.027.

Lucchesi, P. M. A., Arroyo, G. H., Etcheverría, E. I., Parma, A. E., \& Seijo, A. C. (2004). Recommendations for the detection of Leptospira in urine by PCR. Revista da Sociedade Brasileira de Medicina Tropical, 37(2), 131-134. 10.1590/S0037-86822004000200003.

Mansell, C., \& Benschop, J. (2014). Leptospirosis is an important multi-species zoonotic disease in New Zealand. New Zealand Veterinary Journal, 127(1388), 1175-8716. http://journal.nzma.org.nz/journal/127-1388/5980/. 
Martins, G., \& Lilenbaum, W. (2014). Leptospirosis in sheep and goats under tropical conditions. Tropical Animal Health and Production, 46(1), 11-17. $10.1007 / \mathrm{s} 11250-013-0480-6$

Miraglia, F., Moreno, L. Z., Morais, Z. M., Langoni, H., Shimabukuro, F. H., Dellagostin, O. A., Hartskeerl, R., Vasconcellos, S. A., \& Moreno, A. M. (2015). Characterization of Leptospira interrogans serovar Pomona isolated from swine in Brazil, The Journal of Infecion in Developing Coutries, 9(10), 1054-1061. $10.3855 /$ jidc.5507.

Monahan, A. M,. Callanan, J. J., \& Nally, J. E. (2009). Review paper: Host-pathogen interactions in the kidney during chronic leptospirosis. Veterinary Pathology, 46(5), 792-801. 10.1354/vp.08-VP-0265-N-REV.

Picardeau, M. (2013). Diagnosis and epidemiology of leptospirosis. Médecine et maladies infectieuses-NLM, 43(1), 1-9. 10.1016/j.medmal.2012.11.005.

Pinto, P. S., Libonati, H., Penna, B., \& Lilenbaum, W., (2016). A systematic review on the microscopic agglutination test seroepidemiology of bovine leptospirosis in Latin America. Tropical Animal Health and Production, 48(2), 239-248. 10.1007/s11250-015-0954-9.

Rocha, B. R., Balaro, M., Pereira, P. V., Martins, G., \& Lilenbaum, W. (2018). Chronic experimental genital leptospirosis with autochthonous Leptospira santarosai strains of serogroup Sejroe. Small Ruminant Research, 164(1), 28-31. https://doi.org/10.1016/j.smallrumres.2018.04.015.

Rocha, B. R., Balaro, M., Pereira, P. V., Martins, \& G., Lilenbaum, W. (2017). Molecular demonstration of intermittent shedding of Leptospira in cattle and sheep and its implications on control. Ciência Rural, 47(8), 1-4. 10.1590/0103-8478cr20170088.

Silva, A. F., Farias, P. J. A., Silva, M. L. C. R., Araújo Júnior, J. P, Malossi, C. D., Ullmann, L. S., Costa, D. F., Higino, S. S. S., Azevedo, S. S., \& Alves, C. J. (2018). High frequency of genital carriers of Leptospira sp. in sheep slaughtered in the semi-arid region of northeastern Brazil. Tropical Animal Health and Production, 51(1), 43-47. 10.1007/S11250-018-1657-9.

Silva, E. F., Santos, C. S., Athanazio, D. A., Seyffert, N., Seixas, F. K., Cerqueira, G. M., Fagundes, M. Q., Brod, C. S., Reis, M. G., Dellagostin, O. A., \& Ko, A. I. (2008). Characterization of virulence of Leptospira isolates in a hamster model. Vaccine, 26(31), 3892-3896. 10.1016/j.vaccine.2008.04.085.

Stoddard, R. A., Gee, J. E., Wilkins, P. P., McCaustland, K., \& Hoffmaster, A. R. (2009). Detection of pathogenic Leptospira spp. through TaqMan polymerase chain reaction targeting the LipL32 gene. Diagnostic Microbiology and Infectious Disease, 64(3), 247-255. 10.1016/j.diagmicrobio.2009.03.014.

Subharat, S., Wilson, P., Heuer, C., \& Collins-Emerson, J. (2012). Longitudinal serological survey and herd-level risk factors for Leptospira spp. serovars Hardjo-bovis and Pomona on deer farms with sheep and/or beef cattle. New Zeland Veterinary Journal, 60(4), 215-222. 10.1080/00480169.2012.663323.

Suepaul, S. M., Carringtonb, C. V., Campbell, M., Bordea, G., \& Adesiyuna, A. A. (2010). Study on the efficacy of Leptospira vaccines developed from serovars isolated from Trinidad and comparison with commercial vaccines using a hamster model. Vaccine, 28(33), 5421-5426. 10.1016/j.vaccine.2010.06.019

Sullivan, N. D. (1970). Experimental infection of pregnant cows with Leptospira Hardjo. Australian Veterinary Journal, 46(4), 123-125. https://doi.org/10.1111/j.1751-0813.1970.tb01969.x.

Vallée, E., Heuer, C., Collins-Emerson, J. M., Benschop, J., \& Wilson, P. R. (2015). Serological pat-terns, antibody half-life and shedding in urine of Leptospira spp. in naturally exposed sheep. New Zeland Veterinary Journal, 63(6), 301-313. 10.1080/00480169.2015.1049668.

Vallée, E., Ridler, A. L., Heuer, C., Collins-Emerson, J.M., Benschop, J., \& Wilson, P. R. (2017). Effectiveness of a commercial leptospiral vaccine on urinary shedding in naturally exposed sheep in New Zealand. Vaccine. 35(9), 1362-1368. 10.1016/j.vaccine.2016.04.037.

Vermunt, J. J., West, D. M., Cooke, M. M., Alley, M. R., \& Collins-Emerson, J. (1994). Observations on three outbreaks of Leptospira interrogans serovar Pomona infection in lambs. New Zeland Veterinary Journal, 42(4), 133-139. 10.1080/00480169.1994.35803.

World Organization for Animal Health (OIE), Leptospirosis, in: Manual of Diagnostic Tests and Vaccines for Terrestrial Animals, World Organization for Animal Health, Paris, (2014). http://wahis2-devt.oie.int/fileadmin/Home/fr/Health_standards/tahm/2.01.09_LEPTO.pdf. 